VERZEICHNISS DER PUBLICATIONEN DES VERSTORBENEN PROFESSORS SELIM IEMSTRÖM.

\title{
ERNST BIESE.
}

Academische Dissertationen:

Om Volta-induktionsstrómmarnes intensitets fórlopp, Helsingfors, 1869. (Auch abgekürzt, französisch, in Kongl. Svenska Veterıskapsakademiens handlingar, Bd. 8; Referat in Pogg. Ann., I872, und in Archives des Sciences physiques et nat. de Genève, I872.)

Om den elektriska urladdningen i polarljuset och polarljusspektrum, Helsingfors, 1873 . (Auch in Ófvers. af Finska Vet. Soc. forhandl. XV, I873, und in Archives de Genève, I875-76.)

On orsakerna till jordens magnetiska tillstind, Helsingfors, I88o.

In Acta Societatis scientiarum fennicae :

Tome XI. Redogórelse tór justering och undersókning af de enligt K. Senatens uppdrag fór Finska statens rákning frín Frankrike och Sverige anskaffade normal-matt och vigter, i 880.

Tome XVII, I889. J. J. Nervandet's galvanometer.

Tome XX, I895. On night-frosts and the means of preventing their ravages.

Tome XXII, I896. Minnestal 6fver Adolf Moberg.

Tome XXIX, I902. Sur la mesure des courants electriques de l'atmosphère par des appareils à pointes (Auch separat in schwedischer Sprache).

In Ófversigt af Finska Vetenskaps-Societetens Forhandlingar:

BdXIV, 1872. Redogórelse for en på uppdrag af Finska Vet.-Soc. under hósten r87r utford vetenskaplig expedition und Redogorelse for inspelstionen af Finska Vet.-Soc. meteorologiska stationer och på desamma befinttiga meteorologiska instrumenter.

Bd XVI, i874. Om en metod att fylla Carometerrór med qvicksilfver.

Bd XVIII, I876. On teorin for polarljuset, med anledning af iakttagelser af nagra ljusfenomen i geisslerska vor.

$\mathrm{Bd} \mathrm{XXV}, \mathrm{I} 88_{3}$. Fors6k angliende polarljuset under finska polarexpeditionen i Lappland; und fórslag till undersókning af den elektriska str6m, som frambringar polarljuset; und Om polarstationen i Sodankylá.

Bd XXVI, I884. Plan for undersókning af polarljuset; und Om finska polarexpeditionen; und Om finska polarexpeditionens arbeten.

Bd XXXII, I8go. Beráttelse ófver Finska Vet.-Soc. $s$ Meteorologiska Centralanstalts verksamhet frin Maj me̊nad I889 till Maj månad I89o; und Om inforande af luftelektriska observationer vid hárvarande Meteorologiska Centralanstalt.

Bd XXXVI, I894, I frigan om nattfrosterna. 
Bd $\mathrm{XL}, \mathrm{I} 898$. On the variations in the velocity of winds, by $\mathrm{S}$. Lemström and J. Dannholm.

Bd XI,I, rgoo. On the earth-currents and the electrical currents in the atmosphere and their relations to the earth-magnetism. Luminous phenomena, natural and artificial, of the nature of the polar light.

Bd XLIII, Igor. On the state of liquids in capillary tubes under influence of electrical air-currents. (Auch deutsch in Annalen d. Phys. Vierte Folge, Band 5, und schwedisch in Bih. t. K. Svenska Vet.-Akad. Handlingar, Bd. 27, Afd. I. No 2.)

In Bidrag till kannedom af Finlands natur och folk:

Bd XXII, I885. Om den Finska polarexpeditionen till Sodankylá och Kultala jemte skildringar från Lappland af expeditionens medlemmar. (Auch in finnischer Sprache.)

In Exploration internationale des régions polaires:

Expédition polaire finlandaise. Tome I, Météorologie, Helsingfors, I 886; Tome II, Magnétisme terrestre, Helsingfors, I887; Tome III, Electricité atmosphérique, Courants telluriques, Courant électrique de l'atmosphère, Phenomènes lumineux de l'aurore boréale, naturels et artificiels. Helsingfors, I\$98.

\section{Uebrige Publicationen :}

Observationer af luftelektriciteten och polarljuset under 1868 ärs Svenska polarexpedition in Ófvers. af K. Vet.-Akad. Fórh., I869, No. 7 .

Om periodiska fórándringar i några meteorologiska fenomen, deras samband med fórándringar i solen och sannolika inflytande på ärsváxten, in Finsk Tidskrift, T. IV. H. 6, Helsingfors, I878.

L'aurore boréale. Etude générale des phénoménes produits par les courants électriques de l'atmosphère. Paris, 1886 (Auch in schwedischer Sprache “Om polarljuset," Stockholm, I886).

Om elektricitetens inflytande på váxterna, Helsingfors, I89o.

Experiments on the influence of electricity on growing vegetables or plants, in "Electrical Review" I898, read before Sect. A. of the British Assoc. for the Advancement of Science, Bristol, I898.

Några resultat af den "Finska Polarstationens arbeten i Sodankyla och Kuttala åren I882-84, Helsingfors, I899.

Om elektricitetens inflytande på váxande plantor II, Helsingfors̀ I90I.

Elektrocultur. Erhöhung der Ernte-Erträge aller Kultur-Pflanzen durch elektrische Behandlung. Autorisierte Übersetzung von Dr. Otto Pringsheim, Berlin, I902.

Un nouveau type de machine à influence, in Fórh. vid Nordiska Naturforskare-och Lákoremótet i Helsingfors, 1902, Sekt. II.

Des courants électriques de l'air, 1 . c.

Om vátskors fórhållande i kapillar-vór under inflytande af en elektrisk luftstróm, II, Helsingfors, I903.

Electricity in Agriculture and Horticulture, London, I904. 